\title{
Microbial Mechanisms for Remediation of Hexavalent Chromium and their Large-Scale Applications; Current Research and Future Directions
}

\author{
Amr $^{\text {Arishi }}{ }^{1 *}$ (D) and Ibrahim Mashhour ${ }^{2}$ (iD \\ ${ }^{1}$ Department of Botany \& Microbiology, College of Science, King Saud University, Riyadh 11451, Saudi Arabia. \\ ${ }^{2}$ Nuclear Science Research Institute (NSRI), King Abdulaziz City for Science and Technology (KACST), Riyadh, \\ Saudi Arabia.
}

\begin{abstract}
The increase of anthropogenic activities has led to the pollution of the environment by heavy metals, including chromium $(\mathrm{Cr})$. There are two common oxidative states of $\mathrm{Cr}$ that can be found in industrial effluents the trivalent chromium $\mathrm{Cr}$ (III) and the hexavalent chromium $\mathrm{Cr}(\mathrm{VI})$. While the hexavalent chromium $\mathrm{Cr}(\mathrm{VI})$ is highly toxic and can trigger serious human health issues, its reduced form, the trivalent chromium $\mathrm{Cr}(\mathrm{III})$, is less toxic and insoluble. Leather tanning is an important industry in many developing countries and serves as a major source of $\mathrm{Cr}(\mathrm{VI})$ contamination. Globally, tannery factories generate approximately $\mathbf{4 0}$ million $\mathrm{m}^{3}$ of $\mathrm{Cr}$-containing wastewater annually. While the physico-chemical treatments of tannery wastewater are not safe, produce toxic chemicals and require large amounts of chemical inputs, bioremediation using chromium-resistant bacteria (CRB) is safer, efficient and does not produce toxic intermediates. Chromium-resistant bacteria (CRB) utilise three mechanisms for $\mathrm{Cr}(\mathrm{VI})$ removal: biotransformation, biosorption and bioaccumulation. This review will evaluate the three $\mathrm{Cr}(\mathrm{VI})$ detoxification mechanisms used by bacteria, their limitations and assess their applications for large-scale remediation of $\mathrm{Cr}(\mathrm{VI})$. This can be helpful for understanding the nature of $\mathrm{Cr}(\mathrm{VI})$ remediation mechanisms used by bacteria, therefore, bridging the gap between laboratory findings and industrial application of microorganisms for $\mathrm{Cr}(\mathrm{VI})$ removal.
\end{abstract}

Keywords: Bioremediation, Chromium-Reducing Bacteria, Contamination, Tannery Effluents, Toxicity

\begin{abstract}
*Correspondence: aarishi1@ksu.edu.sa; +966-50-248-1588
(Received: December 08, 2020; accepted: January 26, 2021)

Citation: Arishi A, Mashhour I. Microbial Mechanisms for Remediation of Hexavalent Chromium and Their Large-Scale Application; Current Research and Future Directions. J Pure Appl Microbiol. 2021;15(1):53-67. doi:10.22207/JPAM.15.1.32

(C) The Author(s) 2021. Open Access. This article is distributed under the terms of the Creative Commons Attribution 4.0 International License which permits unrestricted use, sharing, distribution, and reproduction in any medium, provided you give appropriate credit to the original author(s) and the source, provide a link to the Creative Commons license, and indicate if changes were made.
\end{abstract}




\section{INTRODUCTION}

The unprecedented growth of human populations, coupled with the increase of industrial activities, has led to the pollution of the environment by different organic and inorganic substances. Chromium ( $\mathrm{Cr}$ ) is a metal abundant in natural environments and in toxic concentrations in effluents generated from industrial activities, including in the fabricated metal industry, leather tanning, dying, coal combustion, oil combustion, the metal mining industry and so forth $^{1}$. Notably, for the last two decades, $\mathrm{Cr}$ has been classified as one of the top 20 highly toxic metallic elements on the superfund priority list of hazardous substances ${ }^{2}$. In a report released in 2015, by the Blacksmith Institute (Pure Earth), $\mathrm{Cr}$ was considered as one of the top six toxic contaminants and was estimated to impact 16 million people and cause 3 million disabilityadjusted life years (DALYs) ${ }^{3}$. Understanding the nature of $\mathrm{Cr}$ is, therefore, critical to developing strategies to ensure removal of this metal from the environment.

In the environment, there are two stable

forms of $\mathrm{Cr}$ : the trivalent chromium $\mathrm{Cr}(\mathrm{III})$ and the hexavalent chromium $\mathrm{Cr}(\mathrm{VI})$. $\mathrm{Cr}(\mathrm{VI})$ has a high level of toxicity and can trigger serious human health issues, including cancers, liver damage and pulmonary congestion illness ${ }^{4-7}$. Meanwhile, $\mathrm{Cr}(\mathrm{III})$ is relatively less toxic and can be removed from wastewater ${ }^{8}$. The devastating effect of $\mathrm{Cr}(\mathrm{VI})$ results from the fact that it can use sulphate transport channels to enter into living cells ${ }^{9}$. Within the cells, the reduction of $\mathrm{Cr}(\mathrm{VI})$ to $\mathrm{Cr}$ (III) leads to the formation of reactive oxygen species (ROS), which can damage living organisms through interacting with nucleic acids and proteins ${ }^{10,11}$.

In the conventional leather tanning industry, crude animal skin is treated to create various leather products and is a major source of $\mathrm{Cr}(\mathrm{VI})$ pollution. Skin treatment involves four main stages, including pre-tanning, chrome tanning, post-tanning and finishing. During these processes, $\mathrm{Cr}(\mathrm{III})$ is oxidised into $\mathrm{Cr}(\mathrm{VI})$, which is then discharged into the environment alongside other metals. As reviewed by Dabai \& Mohammed, on a global scale tanning factories generate approximately 40 million $\mathrm{m}^{3}$ of $\mathrm{Cr}$-containing wastewater annually ${ }^{12}$. Leather tanning is an important industry in many developing countries, including India. In India, the massive leather tanning industry annually leaks between 2000 and 3000 tonnes of $\mathrm{Cr}$ into the surroundings, causing an estimated final concentration of 2000 to 5000 $\mathrm{mg} / \mathrm{L} \mathrm{Cr}$ in the environment ${ }^{13}$. A single operating tannery factory can create groundwater pollution in a 7 to $8 \mathrm{~km}$ radius ${ }^{14}$. Therefore, the removal of $\mathrm{Cr}$ is paramount to protect human health as well as to prevent the long-term irreversible damage that can occur to the environment.

The most common way of treating tannery wastewater is conventional methods (or physicochemical treatment), which include electrochemical treatment, reverse osmosis and ion exchange. Nevertheless, the use of such methods is usually associated with a high energy input and generates toxic by-products that cause secondary pollution ${ }^{15,16}$. Therefore, there is a dire need for an alternative, cost-effective and environmentally friendly approach to remove $\mathrm{Cr}(\mathrm{VI})$ contamination.

Bioremediation is a microbially driven approach which uses microorganisms to remove toxic pollutants from the environment. Certain microorganisms, such as bacteria, fungi, archaea and algae, are capable of tolerating and reducing $\mathrm{Cr}(\mathrm{VI})$, hence remediating $\mathrm{Cr}$ contamination ${ }^{17,18}$. This review will primarily focus on the use of bacteria to detoxify $\operatorname{Cr}(\mathrm{VI})$ contamination. The mechanism used to remove $\mathrm{Cr}(\mathrm{VI})$ can vary on the basis of biogeochemical conditions, means of nutrient utilisation by bacteria and the presence/absence of oxygen in the environment. Understanding these mechanisms used by bacteria to reduce the toxicity of $\mathrm{Cr}(\mathrm{VI})$ will enhance future applications of microbial communities to remove $\mathrm{Cr}$ contamination from an environment. This review will evaluate the three $\mathrm{Cr}(\mathrm{VI})$ detoxification mechanisms used by bacteria, their limitations and assess their applications for large-scale remediation of $\mathrm{Cr}(\mathrm{VI})$.

\section{Microbial Remediation of Hexavalent Chromium}

Bioremediation of $\mathrm{Cr}(\mathrm{VI})$ using bacteria is a promising approach owing to the fact that it is safe, efficient and does not produce toxic intermediates. In numerous research studies, bacteria have shown the potential to detoxify $\mathrm{Cr}(\mathrm{VI})$ by three different mechanisms, including biotransformation, biosorption and bioaccumulation ${ }^{19-21}$. Biotransformation involves 
direct and indirect reduction of toxic $\mathrm{Cr}(\mathrm{VI})$ to $\mathrm{Cr}(\mathrm{III})^{9}$. The transformation process principally relies on the availability of oxygen and an appropriate electron donor ${ }^{9}$. Biosorption is a passive physico-chemical process between $\mathrm{Cr}(\mathrm{VI})$ and bacteria in which both dead and living cells can participate. Nevertheless, the dead cells are proven to be more effective ${ }^{20}$. Bioaccumulation is active uptake of $\mathrm{Cr}(\mathrm{VI})$ by live bacteria that depends on the concentration of the metal and the time of contact with the microbe ${ }^{22}$. CRB using any of the three mechanisms can be a potential biological agent for large-scale microbial remediation of $\mathrm{Cr}(\mathrm{VI})$. A large number of bacteria were isolated and tested for their ability for $\mathrm{Cr}(\mathrm{VI})$ bioremediation (Table 1). In the following subsections, the three major bacterial mechanisms for $\mathrm{Cr}(\mathrm{VI})$ detoxification are scrutinised, and their use in large-scale remediation in bioreactors is critically evaluated.

\section{Biotransformation}

In the biotransformation approach, the highly toxic hexavalent $\mathrm{Cr}(\mathrm{VI})$ is chemically transformed to the less toxic and more stable form of trivalent $\mathrm{Cr}$ (III) via the reduction reaction of $\mathrm{Cr}$-reducing bacteria (CRB) using a gene called $c h r R$. The reduced $\mathrm{Cr}(\mathrm{VI})$ is then expelled from the cells by a mechanism called "efflux pumps" by the actions of the chrA gene ${ }^{23}$. Bacterial transformation of $\mathrm{Cr}(\mathrm{VI})$ can occur either directly through an enzymatic reduction reaction or indirectly by the metabolic end products of other microbes, such as $\mathrm{Fe}(\mathrm{II})$ and $\mathrm{H}_{2} \mathrm{~S}$ of sulfate-reducing bacteria (SRB) and iron-reducing bacteria (IRB) ${ }^{24,25}$. The efficiency of $\mathrm{Cr}(\mathrm{VI})$ reduction differs on the basis of the carbon source available to the bacteria ${ }^{26}$.

Under aerobic conditions, some CRB have shown a unique ability to detoxify $\operatorname{Cr}(\mathrm{VI})$, using industrial waste as a carbon source. A study demonstrated that a locally isolated CRresistant bacterium known as Acinetobacter haemolyticus was able to resist $100 \mathrm{mg} / \mathrm{L}$ of $\mathrm{Cr}(\mathrm{VI})$ and reduce more than $90 \%$ of $\mathrm{Cr}(\mathrm{VI})$ as it grew on sugarcane bagasse waste, compared to Luria Bertan medium, which showed only $25 \%$ reduction ${ }^{27}$. Bacterial species have different preferences for carbon sources. Although glucose can promote the growth of many species, it can also limit the $\mathrm{Cr}(\mathrm{VI})$ reduction ability of some CRB. In a study that tested the detoxification ability of Pannonibacter phragmitetus LSSE-09 using different carbon sources noted the high growth rate of the species on glucose; however, limited reduction was observed compared to with using acetate as the carbon source ${ }^{28}$. On the contrary, glucose can enhance $\mathrm{Cr}(\mathrm{VI})$ reduction for other species. Evidently, the addition of $1 \%$ of glucose to a culture of Bacillus sp. (strain XW4) increased the reduction of $\mathrm{Cr}(\mathrm{VI})$ significantly $\mathrm{y}^{29}$. Although the Bacillus sp. showed a complete reduction under a concentration of $40 \mathrm{mg} / \mathrm{L} \mathrm{CR}(\mathrm{VI})$, it was not able to reduce one of $100 \mathrm{mg} / \mathrm{L}$ of $\mathrm{Cr}(\mathrm{VI})^{29}$. Apparently, $100 \mathrm{mg} / \mathrm{L}$ of $\mathrm{Cr}(\mathrm{VI})$ was high enough to halt the metabolic activity of the bacterium leading to the failure of the reduction pathway.

Under anaerobic conditions, $\mathrm{Cr}(\mathrm{VI})$ is used as terminal electron acceptor ${ }^{30}$. In an experiment that used Burkholderia cepacia MCMB-821 to detoxify $\mathrm{Cr}(\mathrm{VI})$ found that the addition of $2 \%$ of lactose facilitated the reduction of $75 \mathrm{mg} / \mathrm{L}$ of $\mathrm{Cr}(\mathrm{VI})$ by $98 \%^{31}$. Meanwhile, other electron donors such as ethanol, methanol and sodium acetate decreased the transformation ability of the species ${ }^{31}$. In addition, anaerobic species such as sulphate- and iron-reducing bacteria (SRB and IRB) are significant contributors to the reduction of $\mathrm{Cr}(\mathrm{VI})$. The combination of IRB and SRB is estimated to provide reduction that is roughly 100 times faster than when the CRB are the only species used for bioremediation ${ }^{24,32}$. Nevertheless, the activities of many important hydrogenases enzymes required for the reduction were inhibited under high concentrations of $\mathrm{Cr}(\mathrm{VI})^{24}$. Altogether, the efficiency of the biotransformation approach is based on the availability of an appropriate electron donor and is significantly affected under high concentration of $\mathrm{Cr}(\mathrm{VI})$ in the environment.

\section{Biosorption}

The removal of $\mathrm{Cr}(\mathrm{VI})$ through biosorption mechanism is based on a passive physico-chemical process between the heavy metal species and the bacteria in which microorganisms can trap $\mathrm{Cr}(\mathrm{VI})$ and make it immobile and unavailable for biological uptake $^{33}$. In the biosorption mechanism, no energy is needed for metal uptake. Furthermore, the uptake of $\mathrm{Cr}(\mathrm{VI})$ continues until it reaches equilibrium between absorbed ions and the ions in the solution ${ }^{30,33}$.

The ability of dry microbial biomass to take up $\mathrm{Cr}(\mathrm{VI})$ from the environment is more 
efficient in dead than in living cells. Evidently, a comparative analysis of uptake of $\mathrm{Cr}(\mathrm{VI})$ ions in dead and living cells of Bacillus sphaericus in a controlled environment found that metabolically inactive cells were 13 to $20 \%$ better than living cells at $\mathrm{pH} 2.5$ at absorbing $\mathrm{Cr}(\mathrm{VI})^{20}$. In this study, B. sphaericus OT4b31 showed a $44.5 \%$ uptake of 30 $\mathrm{mg} / \mathrm{L}$ of $\mathrm{Cr}(\mathrm{VI})$, compared to a $25 \%$ uptake for living cells, and B. sphaericus IV(4)10 showed $32 \%$ and $45 \%$ for living and dead biomass, respectively ${ }^{20}$. In addition to this, using dead microbial biomass to take up $\mathrm{Cr}(\mathrm{VI})$ is the most effective approach to overcome the $\mathrm{pH}$ barrier. In a study that used dried biomass of Bacillus thuringiensis under $250 \mathrm{mg} / \mathrm{L}$ of $\mathrm{Cr}(\mathrm{VI})$ and at $\mathrm{pH} 2$ revealed that $B$. thuringiensis was able to absorb $24.1 \%$ of $\mathrm{Cr}(\mathrm{VI})^{34}$.

Nevertheless, the use of the biosorption approach might not be an effective solution when $\mathrm{Cr}(\mathrm{VI})$ is not the only metal in the effluents. Alongside with $\mathrm{Cr}(\mathrm{VI})$, industrial effluents contain large amounts of cadmium, or $\mathrm{Cd}(\mathrm{II})^{35}$. The presence of $\mathrm{Cd}(\mathrm{II})$ in the environment can reduce the biosorption of $\mathrm{Cr}(\mathrm{VI})$, as $\mathrm{Cd}(\mathrm{II})$ is preferred by some types of microbial biomass. In a binary system experiment in which Staphylococcus xylosus and Pseudomonas sp. were grown on a medium enriched with $\mathrm{Cr}(\mathrm{VI})$ and $\mathrm{Cd}(\mathrm{II})$ demonstrated a profound selectivity for $\mathrm{Cd}$ (II) ions against $\mathrm{Cr}(\mathrm{VI})$ ions $^{36}$. Therefore, biosorption is an effective approach when $\mathrm{Cr}(\mathrm{VI})$ is the dominant metal in the effluents. This can be problematic for in situ applications, as the biosorption might shift towards another metal.

\section{Bioaccumulation}

Bioaccumulation of $\mathrm{Cr}(\mathrm{VI})$ from the environment is a metabolism-dependent mechanism that requires energy to be spent for the transportation of $\mathrm{Cr}(\mathrm{VI})$ reversibly across the membrane. Therefore, only living microbial cells can be used to take up $\mathrm{Cr}(\mathrm{VI})$ from an environment. As the chemical structure of $\mathrm{Cr}(\mathrm{VI})$ ions resembles that of other ions such as tetrahedral sulphate (SO4 ${ }^{2-}$ ) (Fig. 1), $\mathrm{Cr}(\mathrm{VI})$ ions move across the bacterial membrane by utilising the $\mathrm{SO}^{2-}$ transport pathways ${ }^{9}$.

Several studies documented the use of microbial communities to take up $\mathrm{Cr}(\mathrm{VI})$ from an environment through the bioaccumulation approach. Certain bacterial species have a distinct surface protein referred to S-layer that can entrap metallic ions on the cell membrane $e^{20}$. In a labscale study, two bacterial species $-B$. sphaericus OT4b31 and $B$. spaericus IV(4)10 - were able to accumulate 25 to $32 \mathrm{mg} / \mathrm{L} \mathrm{Cr}(\mathrm{VI})^{20}$. Bacteria can show a different ability in accumulating $\mathrm{Cr}(\mathrm{VI})$ ions. In an experiment that used indigenous microbial strains to remove $\mathrm{Cr}(\mathrm{VI})$ from the environment showed that Klebsiella pneumoniae MB361 was able to accumulate an $83.51 \% \mathrm{Cr}(\mathrm{VI})$ concentration between 500 and $1000 \mathrm{ug} / \mathrm{ml}$ under a neutral $\mathrm{pH}$ condition ${ }^{37}$. In another study, two species of bacteria isolated from tannery effluents which contain $0.96 \mathrm{mg} / \mathrm{L}$ of $\mathrm{Cr}(\mathrm{VI})$, - Bacillus megaterium (strain A) and Bacillus coagulans (181) - showed remarkable capacity, accumulating 15.7 and 23.8 $\mathrm{mg} \mathrm{Cr} / \mathrm{g}$ of the microbial dry weight, respectively, in just $24 \mathrm{hr}^{21}$. Some metabolically active microbial cells can tolerate a high concentration of $\mathrm{Cr}(\mathrm{VI})$ when it is incubated with $5 \%$ of industrial effluents. B. cereus strain IST105 isolated from electroplating effluent demonstrated $>75 \%$ removal of $\mathrm{Cr}(\mathrm{VI})$ within a five-day period when living cells were used $^{38}$

Nonetheless, the physiological activity of many metabolically active microbial cells can be negatively impacted at high concentrations of the

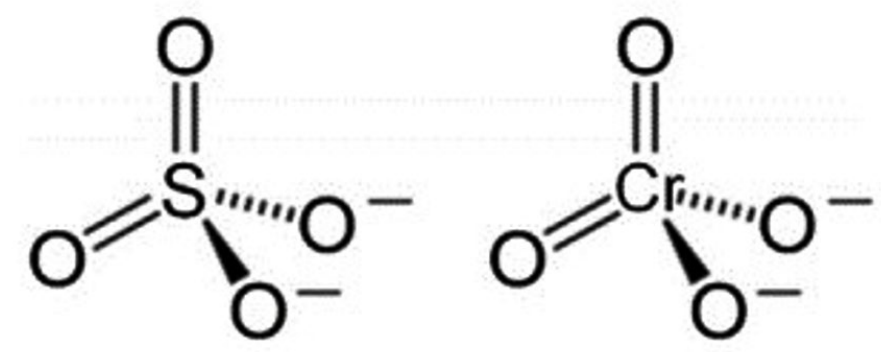

Fig. 1. Structural similarity of chromate and sulfate ions; adapted from Thatoi et al. ${ }^{9}$ 
pollutant as well as at low $\mathrm{pH}$ levels. In a study that used living cells of Acinetobacter junii VITSUKMW2 under $\mathrm{pH}$ levels between 5 and 11 to remove $\mathrm{Cr}(\mathrm{VI})$ reported that the growth and the reduction ability of the bacterium were significantly reduced when the $\mathrm{pH}$ was adjusted to 5 and reached a peak at a pH of $9^{39}$. Furthermore, as the bioaccumulation mechanism is energy-dependent, under high concentrations of the pollutant, the metabolic activity can be significantly affected ${ }^{29}$. Therefore,

Table 1. List of bacteria and their mechanisms for $\mathrm{Cr}(\mathrm{VI})$ detoxification

\begin{tabular}{|c|c|c|}
\hline Name of the bacteria & Bioremediation mechanism & Reference \\
\hline Bacillus sphaericus OT4b31 & Biosorption/Bioaccumulation & 20 \\
\hline Bacillus sphaericus IV(4)10 & Biosorption/Bioaccumulation & 20 \\
\hline Bacillsu cereus IST105 & Biosorption & 38 \\
\hline Pseudomonas aeruginosa & Biosorption & 40 \\
\hline Bacillus subtilis & Biosorption & 40 \\
\hline Acinetobacter haemolyticus & Biotransformation & 27 \\
\hline Enterococcus casseliflavus & Biosorption & 41 \\
\hline Corynebacterium paurometabolum & Biosorption/Biotransformation & 42 \\
\hline Bacillus megaterium & Biosorption/Bioaccumulation & 21 \\
\hline Bacillus coagulans & Biosorption/Bioaccumulation & 21 \\
\hline Pseudomonas gessardii LZ-E & Biotransformation & 19 \\
\hline Shewanella putrefaciens & Biotransformation & 43 \\
\hline Thiobacillus ferrooxidans DSM 11477 & Biotransformation & 44 \\
\hline Methanothermobacter thermautotrophicus & Biotransformation & 45 \\
\hline Staphylococcus xylosus & Biosorption & 36 \\
\hline Bacillus sp. MGG-83 & Biosorption & 46 \\
\hline Bacillus amyloliquifaciens & Biotransformation & 47 \\
\hline Microbacterium spp. & Biotransformation & 48 \\
\hline Staphylococcus aureus K1 & Biotransformation & 49 \\
\hline Stenotrophomonas maltophilia & Biotransformation & 50 \\
\hline Escherichia coli FACU & Biotransformation & 51 \\
\hline Acidiphilium cryptum JF-5 & Biotransformation & 52 \\
\hline Cellulosimicrobium funkei strain AR6 & Biosorption/Bioaccumulation & 53 \\
\hline Mesorhizobium amorphae & Biosorption & 54 \\
\hline Arthrobacter rhombi & Biotransformation & 55 \\
\hline Acinetobacter baumannii L2 & Biosorption/Biotransformation & 56 \\
\hline Pseudomonas stutzeri L1 & Biosorption/Biotransformation & 56 \\
\hline Leucobacter sp. G161 & Biotransformation & 57 \\
\hline Bacillus amyloliquefaciens & Biotransformation & 58 \\
\hline Stenotrophomonas sp. & Biotransformation & 59 \\
\hline Bacillus endophyticus & Biotransformation & 60 \\
\hline Virgibacillus sp. & Biotransformation & 61 \\
\hline Pediococcus acidilactici & Biotransformation & 62 \\
\hline Providencia sp. UTDM314 & Biotransformation & 63 \\
\hline Serratia sp. & Biotransformation & 64 \\
\hline Acinetobacter junii & Biosorption & 65 \\
\hline Pseudomonas aeruginosa $\mathrm{A} 2 \mathrm{Chr}$ & Biotransformation & 66 \\
\hline Burkholderia cepacian MCMB-821 & Biotransformation & 31 \\
\hline Desulfovibrio vulgaris Hildenborough & Biotransformation & 24 \\
\hline Tenotrophomonas sp. MB339 & Bioaccumulation & 37 \\
\hline Klebsiella pneumoniae MB361 & Bioaccumulation & 37 \\
\hline Staphylococcus sp. MB371 & Bioaccumulation & 37 \\
\hline Pannonibacter phragmitetus LSSE-09 & Biotransformation & 28 \\
\hline Bacillus thuringiensis & Biosorption & 34 \\
\hline
\end{tabular}


the low level of $\mathrm{pH}$ as well as the high concentration of pollutants in the environment can lead to the failure of the bioaccumulation approach.

Advantages and Limitations of $\mathrm{Cr}(\mathrm{VI})$ Remediation Using Microbes

Bioremediation using bacteria offers a cost-effective, efficient and sustainable approach to clean the environment from wastewater containing $\mathrm{Cr}(\mathrm{VI})$ through biotransformation, biosorption and bioaccumulation mechanisms.

The biotransformation approach is the most-utilised method for bioremediation of $\mathrm{Cr}(\mathrm{VI})$. Given that the reaction in the biotransformation mechanism is based on the carbon source available for microbes, it needs to be chosen carefully according to the preference of the inoculum ${ }^{26}$. There are many advantages for using the biotransformation approach, such as the reusability of the reduced $\mathrm{Cr}(\mathrm{VI})$ as well as maintaining the viability of the inoculum for future applications. Another benefit is that it allows the use of microbial consortia to catalyse the reaction ${ }^{9,24}$. A microbial consortium of CRB alongside IRB and SRB is a powerful tool to ensure not only faster and complete but also sustainable technology for future application ${ }^{9}$. However, there are disadvantages that need to be addressed, including the loss of cell viability under high concentrations of $\mathrm{Cr}(\mathrm{VI})$ (Table 2) ${ }^{24}$. The reduction pathway is also energy-dependent, and poor selection of an electron donor can limit the biotransformation ability of the bacteria28,29,31.

When the cost of providing nutrient media is a feasibility issue, the biosorption approach is a preferred alternative remediation approach. In particular, using dead microbial biomass to adsorb $\mathrm{Cr}(\mathrm{VI})$ from contaminated matrices is an effective way that does not require energy and thus reduces the cost of $\mathrm{Cr}(\mathrm{VI})$ removal, as dead cells are immune to low $\mathrm{pH}$ levels and allow the recovery of the metal from microbial biomass $^{33}$. One disadvantage is that applied biomass cannot be used for future applications because it is generally converted to powder for $\mathrm{Cr}(\mathrm{VI})$ recovery ${ }^{20}$. Given that the behaviour of microbial biomass under low $\mathrm{pH}$ values can vary, so does its ability to eliminate $\mathrm{Cr}(\mathrm{VI})$ in an acidic environment. To ensure $\mathrm{Cr}(\mathrm{VI})$ removal in the biosorption mechanism, metabolically inactive biomass is used under low $\mathrm{pH}$ values between 2.0 and 5.0, depending on the physico-chemical characteristic of the biomass used ${ }^{20,34}$. However, the presence of multiple metal ions in wastewater can pose a major challenge, as some ions show more affinity to microbial biomass than others ${ }^{36}$.

The bioaccumulation mechanism relies only on using active microbial biomass. Compared to the biotransformation and the biosorption approaches, microbial accumulation of metals received less attention, owing to the fact that it is

Table 2. Comparison of the three $\mathrm{Cr}(\mathrm{VI})$ removal mechanisms

\begin{tabular}{|c|c|c|c|}
\hline Feature & Biotransformation & Biosorption & Bioaccumulation \\
\hline Definition & $\begin{array}{l}\text { The direct or indirect } \\
\text { reduction of } \mathrm{Cr}(\mathrm{VI}) \text { to } \\
\mathrm{Cr}(\mathrm{III})\end{array}$ & $\begin{array}{l}\text { The passive uptake of } \mathrm{Cr}(\mathrm{VI}) \\
\text { ions by the biomass until } \\
\text { reaching equilibrium }\end{array}$ & $\begin{array}{l}\text { The active accumulation } \\
\text { of the } \mathrm{Cr}(\mathrm{VI}) \text { ions by } \\
\text { living cells }\end{array}$ \\
\hline Reduction efficiency & High efficiency & High efficiency & Low efficiency \\
\hline Nature of cells & Only living cells & Both living and dead cells & Only living cells \\
\hline Biomass reusability & Multiple times & Single time & Single time \\
\hline $\mathrm{Cr}(\mathrm{VI})$ recovery & Recovered as $\mathrm{Cr}(\mathrm{III})$ & $\begin{array}{l}\text { Recovered as dry microbial } \\
\text { biomass, which is then } \\
\text { converted to powder }\end{array}$ & $\begin{array}{l}\text { Recovered as dry microbial } \\
\text { biomass, which is then } \\
\text { converted to powder }\end{array}$ \\
\hline $\mathrm{Cr}(\mathrm{VI})$ uptake & - & Rapid accumulation & Slower than biosorption \\
\hline Energy requirement & Spend energy & No energy is needed & Spend energy \\
\hline $\mathrm{pH}$ requirement & $\begin{array}{l}\text { Vary based on the } \\
\text { biomass used }\end{array}$ & $\begin{array}{l}\text { Better } \mathrm{Cr}(\mathrm{VI}) \text { removal under } \\
\text { low } \mathrm{pH}\end{array}$ & Mostly neutral pH \\
\hline Major limitations & $\begin{array}{l}\text { High concentration of } \\
\mathrm{Cr}(\mathrm{VI}) \text { and poor selection } \\
\text { of carbon source can limit } \\
\text { the reduction pathway }\end{array}$ & $\begin{array}{l}\text { Biosorption is a pH dependent } \\
\text { approach and can shift towards } \\
\text { other metals when } \mathrm{Cr}(\mathrm{VI}) \text { is } \\
\text { not the dominant pollutant }\end{array}$ & $\begin{array}{l}\text { High concentration of } \\
\mathrm{Cr}(\mathrm{VI}) \text { and low level of } \mathrm{pH} \\
\text { can inhibit the accumulation } \\
\text { of } \mathrm{Cr}(\mathrm{VI})\end{array}$ \\
\hline
\end{tabular}


a slower process than the biosorption mechanism and can be interrupted under low $\mathrm{pH}$ levels. In the biosorption mechanism, a low $\mathrm{pH}$ value is needed to compensate the lack of protons important for ion exchange. This cannot be done efficiently in living cells for bioaccumulation ${ }^{20}$. Although the use of metabolically active microbes can present a significant advantage over the use of dead cells by performing different metabolic activities, including formation of an extracellular complex, precipitation and transport, using living cells can complicate the recovery of $\mathrm{Cr}(\mathrm{VI})$, which poses a subsequent challenge, particularly if they were precipitated or compartmentalized inside the cells ${ }^{67}$. A major limitation of the bioaccumulation approach is that cell growth can be inhibited as $\mathrm{Cr}(\mathrm{VI})$ accumulates to a toxic level in a cell25,68.

In summary, approaches for $\mathrm{Cr}(\mathrm{VI})$ bioremediation are complicated mechanisms and can be affected by many factors, including $\mathrm{Cr}(\mathrm{VI})$ concentration in the effluents, surface charge, the physico-chemical properties of industrial waste (such as $\mathrm{pH}$ ), the interaction between biomass and metal ions and the interaction within metal ions. In the use of dead microbial biomass, the $\mathrm{pH}$ barrier does not constitute a problem. However, to maximise the $\mathrm{Cr}(\mathrm{VI})$ reduction in using living biomass, the $\mathrm{pH}$ level must be adjusted to the optimum level for boosting the physiological activity of the employed microbe. Bioreactor systems that utilise different $\mathrm{Cr}$ detoxification mechanisms need detailed characterization of waste and inocula for maximum efficiency of $\mathrm{Cr}$ removal.

\section{Large-scale $\mathrm{Cr}(\mathrm{VI})$ Bioremediation Using} Bioreactors

For large-scale removal of $\mathrm{Cr}(\mathrm{VI})$, bioreactors such as fed-batch or continuous reactors are used in which CRB are exploited as biological agents. Bioreactor systems are classified into four different systems based on their applications: a. Stirred-tank reactors; b. Fixedbed reactors; c. Fluidized-bed reactors; $d$. Airlift reactors.

\section{Stirred Tank Bioreactors (STRs)}

The STR system has a stirrer that works in two modes: batch or continuous. Furthermore, this type of bioreactor makes it possible to study the removal of $\mathrm{Cr}(\mathrm{VI})$ at different concentrations. In an experiment to study the

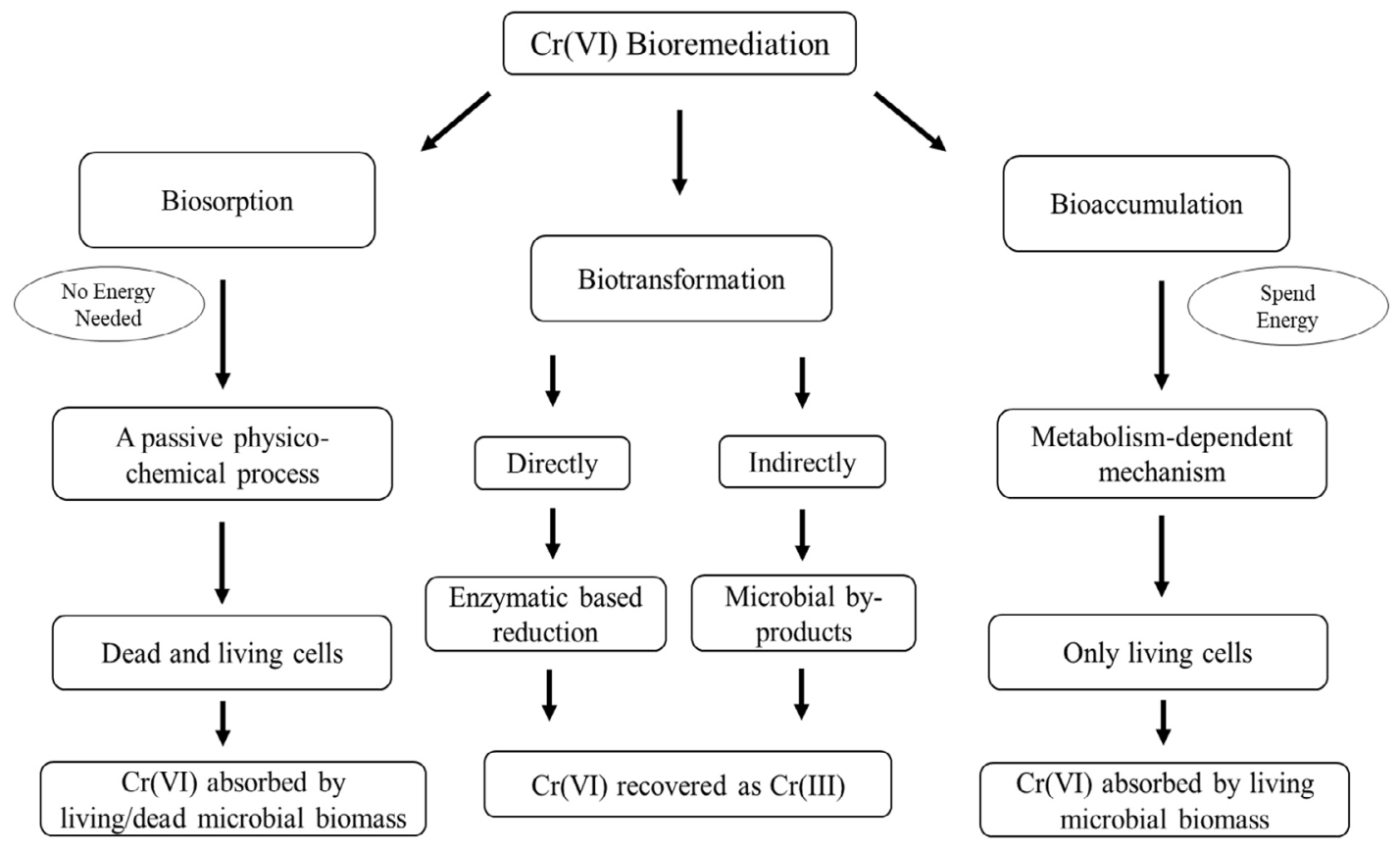

Fig. 2. Schematic illustration of the three $\mathrm{Cr}(\mathrm{VI})$ bioremediation mechanisms. 
$\mathrm{Cr}(\mathrm{VI})$ biotransformation ability of Arthrobacter rhombi-RE strain MTCC7048 grown on molasses as a carbon source using three different growth systems, including an anoxic attached growth, aerobic attached and aerobic suspended system, found that the aerobic attached approach was the most effective, reaching $95 \%$ reduction of $\mathrm{Cr}(\mathrm{VI})$ in an initial concentration of $20 \mathrm{mg} / \mathrm{L}$ and chemical oxygen demand (COD) reduction of between 90 and $95 \%$ in an initial concentration of $3000 \mathrm{mg} /$ $\mathrm{L}^{55}$. Nevertheless, there are drawbacks which may limit the application of the STRs for large-scale remediation. These drawbacks include the cost of high energy consumption, STRs can only be used to treat small quantities of effluents, loss of the viability of the metabolically active microbes and the fact that mixing of different contaminants might shift the remediation pathway ${ }^{36,69,70}$.

\section{Fixed-bed Reactors (FXRs)}

The FXR system is characterised by its simplicity in construction and operation. In this system, the biosorbent is contained in a bed fixed on a column which passes the industrial effluents to be treated ${ }^{71}$. In a study that involved using FXR with immobilized agar-agar that contains a consortium of CRB - namely, Pseudomonas aeruginosa and Bacillus subtilis - the bacteria were able to remove a large amount of heavy metals, including $\mathrm{Cr}(\mathrm{VI})$, from textile effluents in 15 days and to significantly reduce COD from $1200 \mathrm{mg} / \mathrm{L}$ to $200 \mathrm{mg} / \mathrm{L}^{40}$. In another study that involved the use of SRB growing on ethanol in FXR revealed that the bacteria removed $95 \%$ of $50 \mathrm{mg} / \mathrm{L}$ of $\mathrm{Cr}(\mathrm{VI})$ using the biosorption approach ${ }^{72}$. Yet, there are some challenges that may limit the use of FXRs. These challenges include the need for multiple columns to maintain the optimal conditions for $\mathrm{Cr}(\mathrm{VI})$ remediation, and the need to generate a fixed bed when the biosorbent reaches its maximum capacity 25 .

\section{Fluidized-bed Bioreactors (FBRs)}

In FBR system, microbes grow to form a biofilm on a solid surface, and the suspension state of a bed is maintained by continuously movement of the particles the reactor ${ }^{25}$. In an experiment that used an FBRs, E. coli supported kaolin to remove a number of metal ions, including $\mathrm{Cr}(\mathrm{VI})$. The study found that the presence of kaolin increased the biosorption of $\mathrm{Cr}(\mathrm{VI})$ to $100 \%$ at a lower concentration $(8 \mathrm{mg} / \mathrm{L})$ and to approximately
$26 \%$ at $116 \mathrm{mg} / \mathrm{L}^{73}$. In another study that used an FBR system and ethanol as a carbon source, SRB showed high efficiency in $\mathrm{Cr}(\mathrm{VI})$ removal $^{74}$. In this study, SRB was able to remove up to $93 \%$ of 45 $\mathrm{gm} / \mathrm{L}$ of $\mathrm{Cr}(\mathrm{VI})$ from textile wastewater ${ }^{74}$. Despite all the benefits, there are some limitations for using FBRs for large-scale $\mathrm{Cr}(\mathrm{VI})$ remediation, which include the loss of microbial viability as well as potential contamination with other microbes ${ }^{75}$. AirLift Reactors (ALRs)

The function of ALR system is based on reducing shear stress by using an air bubble column alongside an airlift. The system has aeration, which ensures that the amount of needed oxygen has been met and enhances aeration mixture as well as mass transfer ${ }^{25}$. Furthermore, this type of bioreactor works best when the microorganisms used for bioremediation are fungi. In fact, it allows the formation of fungal mycelium, which in turn increases the area of contact. The system has been extensively studied using fungi, including filamentous fungi and yeast, to remove $\mathrm{Cr}(\mathrm{VI})$, but it has been poorly studied for bioremediation by bacteria $^{76,77}$. Additionally, the system offers many benefits, among them lower power consumption, a lack of moving parts, rapid mixing, low risk of contamination and easy sterilization ${ }^{78}$. However, the use of the system is limited to the low-density liquids.

Advantages and Limitations for Using Bioreactors

Using bioreactors is the most efficient approach to scale up the bioremediation ability of the three microbial mechanisms for $\mathrm{Cr}$-removal. The benefits and drawbacks for four bioreactors are discussed below.

Stirred-tank reactors (STRs) comprise one system that can enhance the ability of microbes to remove $\mathrm{Cr}(\mathrm{VI})$ from industrial wastewater via optimising the conditions to boost the microbial performance. There are many advantages to using STRs, including the simplicity of the system, which allows repeatability of experiments, as well as the ability to study the efficiency of the microbial removal approaches at different concentrations of a pollutant ${ }^{78}$. Yet several disadvantages limit the use of STRs for large-scale applications (Table 3). Poor energy efficiency is among these drawbacks, and thus use of STRs often comes with a high operational cost. Another disadvantage is that the system can reach maximum performance only 


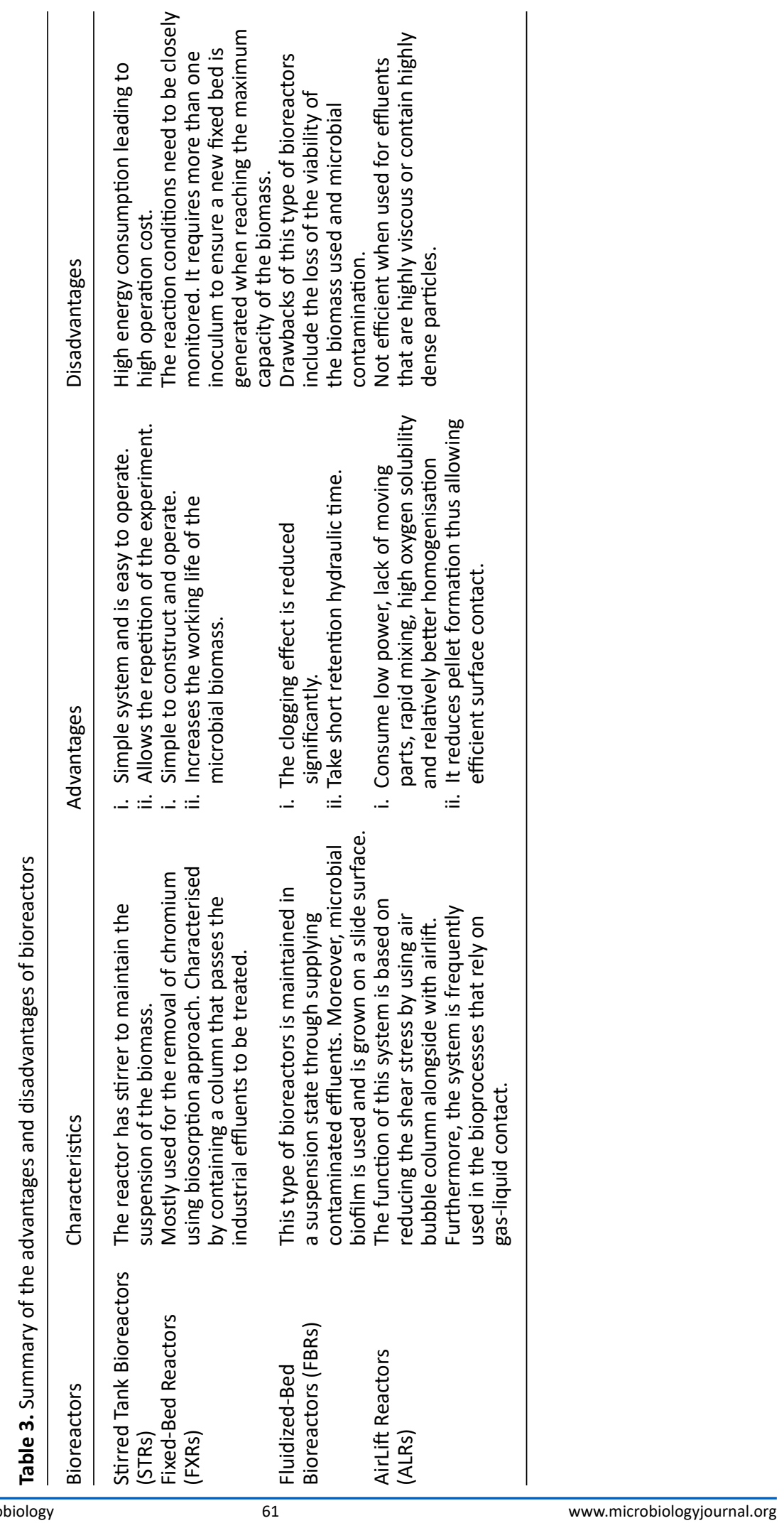


when a small amount of industrial wastewater is used, thus limiting large-scale application ${ }^{62,79}$.

Fixed-bed reactor (FXR) systems are usually used to optimise the $\mathrm{Cr}(\mathrm{VI})$ uptake by microbial biomass. There are many positive aspects of using FXRs, including the simplicity of construction and operation, longer working life for microbial biomass and the allowance of $\mathrm{Cr}(\mathrm{VI})$ recovery through cycles of desorption (Table 3). Additionally, FXRs facilitates the use of large particles for immobilization of biosorbents 66. Some disadvantages, however, might restrict large-scale applications of FXR system, including the need to maintain the reaction condition and the need for multiple inocula to be supplied when the bed has reached its full capacity ${ }^{80,81}$.

Fluidized-bed bioreactors (FBRs) support microbial biomass to form a biofilm on a solid surface. An important feature of FBR system is that the clogging effect is reduced considerably, which allows better flow of supplies to the system and thus achieves better results capacity ${ }^{25}$. Moreover, a shorter retention time makes it more efficient than the other systems (Table 3). Nevertheless, loss of the viability of microbial biomass is a major issue for FBR system. In addition, as the system required constant aeration, there is a high potential of microbial contamination through air flow ${ }^{75}$.

AirLift reactors (ALRs) work by reducing shear stress via an air bubble column coupled with an airlift. The many advantages of using ALR system include low power consumption (cost- effective), mixing of contents at faster rate than in the other systems, low risk of microbial contamination and a lack of moving parts (Table $3)^{77}$. Although there are many benefits for ALR bioreactors, some disadvantages might limit the use of ALRs for large-scale bioremediation. These drawbacks include poor efficiency in dealing with viscous solutions as well as dense particles ${ }^{78}$.

\section{Future Directions}

Several studies were conducted to improve the efficiency of the microbial mechanism for removing $\mathrm{Cr}$. Among these studies, genetic engineering, using microbial consortium, using nano-material and designing higher efficiency bioreactors showed promising results in detoxifying $\mathrm{Cr}$ from the environment. In the following subsections, findings of these studies will be highlighted.

\section{Designing Super-reduction Pathway}

Employing genetic engineering to improve the microbial ability to tolerate high stress resulting from metallic ions is a promising approach. The capabilities of some microbial species to survive in highly toxic environments are attributed to their genetic adaptation to extreme environmental conditions ${ }^{25}$. Therefore, the genetic manipulation of CRB to design a super-reduction pathway can be achieved, specifically for plasmid-mediated $\mathrm{Cr}$ resistance. In a lab-scale study aimed at developing a recombinant bacterium able to reduce elevated levels of $\mathrm{Cr}$, the gene nemA of E.coli and the gene phaC of Ralstonia eutropha were fused to create a novel $\mathrm{Cr}$ reduction system and were transferred to a recombinant microorganism, resulting in the expression of a Cr-reducing enzyme with 200-fold higher reduction efficiency ${ }^{82}$. Such approaches can be used to construct more efficient microbes that can tolerate multiple metals while reducing $\mathrm{Cr}(\mathrm{VI})$.

\section{Using Microbial Consortium}

The application of a microbial consortium is one of the most effective approaches to remove $\mathrm{Cr}(\mathrm{VI})$ from contaminated sites. The use of microbial consortia for large-scale $\mathrm{Cr}$ removal is evident in bioreactors $^{83}$. One application that uses a microbial consortium to remove $\mathrm{Cr}(\mathrm{VI})$ is bioaugmentation, which involves adding metal resistance strain or a consortium to a site of contamination, allowing it to remove contaminants from the site (in suit) ${ }^{84}$. In a study that used Aeromonas hydrophila strain LZMG14 isolated from textile wastewater to develop bioaugmentation strategy in membrane bioreactor revealed that $A$. hydrophila was able to colonise the activated sludge and improve the ability of other microbes to reduce $0.5 \mathrm{mmol} / \mathrm{L}$ of $\mathrm{Cr}(\mathrm{VI})$ by $93.71 \%$ in just $12 \mathrm{hr}^{85}$. Therefore, bioaugmentation using microbial consortia can be an effective tool for $\mathrm{Cr}(\mathrm{VI})$ remediation because it can activate diverse microbial pathways.

\section{Using Nano-material}

Additionally, the use of nanotechnology to improve microbial remediation is another alternative solution. This approach includes using immobilized microbial cells and metabolic enzymes alongside nanotechnology. It not only enhances the stability of the enzymes used for $\mathrm{Cr}(\mathrm{VI})$ reduction but can also promote the remediation of contaminated matrices at a nanometre scale by 
combining CRB with nano-materials that can act as electron donors for the reaction ${ }^{86}$.

Designing Higher Efficiency Bioreactors

Led by the desire to develop a lowcost, biologically based treatment for $\mathrm{Cr}$ contaminated aquatic environments. Williams et al. developed the foundation for building a fixed film pilot bioreactor, which involved using microbial consortia such as Enterobacter cloacae, Flavobacterium sp. and Ralstonia sp. to remove $\mathrm{Cr}(\mathrm{VI})^{87}$. Notably, this was the first effective illustration of upscaled removal of $>99 \%$ of $\mathrm{Cr}(\mathrm{VI})$ from 24,000 L of contaminated groundwater ${ }^{87}$. Another promising means of $\mathrm{Cr}$ removal that can be applied is slurry-phase bioremediation. This slurry-phase reactor is characterized by treating soil in a bioreactor ${ }^{88}$. Adopting these strategies could help in developing an effective large-scale reactor for industrial wastewater treatment.

\section{CONCLUSION}

The widespread discharge of highly toxic $\mathrm{Cr}(\mathrm{VI})$ warrants development of efficient and rapid remediation technologies. Bacteria offer a promising solution to tackle $\mathrm{Cr}(\mathrm{VI})$ contamination in the environment. Three naturally evolved $\mathrm{Cr}$ reducing mechanisms-namely, biotransformation, biosorption and bioaccumulation - are already being utilised, each with advantages and limitations. For an improved remediation of $\mathrm{Cr}(\mathrm{VI})$ using bacteria in bioreactors, multiple factors, including $\mathrm{Cr}(\mathrm{VI})$ concentrations, $\mathrm{pH}$ levels and carbon sources, need to be adjusted to achieve a considerable reduction level. Microbial consortia, genetically modified bacteria and well-designed bioreactors can be the most efficient ways to ensure the removal of hexavalent $\mathrm{Cr}$ from the environment.

\section{ACKNOWLEDGMENTS}

All the listed author(s) are thankful to their representative universities/institutes for providing the related support to compile this work.

\section{CONFLICT OF INTEREST}

The authors declare that there is no conflict of interest.

\section{AUTHORS' CONTRIBUTION}

All the listed author(s) have made a substantial, direct, and intellectual contribution to the work, and approved it for publication.

\section{FUNDING}

None.

\section{DATA AVAILABILITY}

All datasets generated or analyzed during this study are included in the manuscript.

\section{ETHICS STATEMENT}

This article does not contain any studies with human participants or animals performed by any of the authors.

\section{REFERENCES}

1. Cheng H, Zhou T, Li Q, Lu L, Lin C. Anthropogenic chromium emissions in China from 1990 to 2009. PLOS ONE. 2014;9(2):e87753. doi: 10.1371/journal. pone. 0087753

2. Chrysochoou M, Johnston CP. Reduction of chromium (VI) in saturated zone sediments by calcium polysulfide and nanoscale zerovalent iron derived from green tea extract. In GeoCongress 2012:3959-3967. doi: 10.1061/9780784412121.406

3. Pure Earth, Green Cross Switzerland. World's worst pollution problems 2015: The new top six toxic threats priority list for remediation. 2015:46-48. https:// www. worstpolluted.org/docs/WWPP_2015_Final.pdf

4. Stout MD, Herbert RA, Kissling GE, et al. Hexavalent chromium is carcinogenic to $\mathrm{F} 344 / \mathrm{N}$ rats and B6C3F1 mice after chronic oral exposure. Environ Health Perspect. 2009;117(5):716-722. doi: 10.1289/ ehp.0800208

5. Tagliari KC, Vargas VMF, Zimiani K, Cecchini R. Oxidative stress damage in the liver of fish and rats receiving an intraperitoneal injection of hexavalent chromium as evaluated by chemiluminescence. Environ Toxicol Pharmacol. 2004;17(3):149-157. doi: 10.1016/j. etap.2004.04.001

6. Beaver LM, Stemmy EJ, Schwartz AM, et al. Lung inflammation, injury, and proliferative response after repetitive particulate hexavalent chromium exposure. Environ Health Perspect. 2009;117(12):1896-1902. doi: 10.1289/ehp.0900715

7. Deng Y, Wang M, Tian T, et al. The effect of hexavalent chromium on the incidence and mortality of human cancers: a meta-analysis based on published epidemiological cohort studies. Front Oncol. 2019;9:24. doi: 10.3389/fonc. 2019.00024

8. Wu D, Sui $Y$, He S, Wang X, Li C, Kong H. Removal of trivalent chromium from aqueous solution by zeolite synthesized from coal fly ash. J Hazard Mater. 2008;155(3):415-423. doi: 10.1016/j. jhazmat.2007.11.082 
9. Thatoi H, Das S, Mishra J, Rath BP, Das N. Bacterial chromate reductase, a potential enzyme for bioremediation of hexavalent chromium: A review. J Environ Manage. 2014;146:383-399. doi: 10.1016/j. jenvman.2014.07.014

10. Ray RR. Adverse hematological effects of hexavalent chromium: an overview. Interdiscip Toxicol. 2016;9(2):55-65. doi: 10.1515/intox-2016-0007

11. DesMarias TL, Costa M. Mechanisms of chromiuminduced toxicity. Curr Opin Toxicol. 2019;14:1-7. doi: 10.1016/j.cotox.2019.05.003

12. Dabai Al, Mohammed K. Chromium removal from tannery wastewater: a review. Platform: A J Sci Tch. 2020;3(1):63-73.

13. Rameshraja D, Suresh S. Treatment of tannery wastewater by various oxidation and combined processes. International Journal of Environmental Research. 2011;5(2):349-360.

14. Gowd SS, Govil PK. Distribution of heavy metals in surface water of Ranipet industrial area in Tamil Nadu, India. Environ Monit Assess. 2008;136(1-3):197-207. doi: 10.1007/s10661-007-9675-5

15. Witek-Krowiak A. Kinetics and equilibrium of copper and chromium ions removal from aqueous solutions using sawdust. Environmental Engineering \& Management Journal (EEMJ). 2013;12(11). doi: 10.30638/eemj.2013.264

16. Aarthy M, Rajesh T, Thirunavoukkarasu M. Critical review on microbial fuel cells for concomitant reduction of hexavalent chromium and bioelectricity generation. J Chem Technol Biotechnol. 2020;95(5):1298-1307. doi: $10.1002 / j c t b .6257$

17. Bhattacharya A, Gupta A, Kaur A, Malik D. Alleviation of hexavalent chromium by using microorganisms: insight into the strategies and complications. Water Sci Technol. 2019;79(3):411-424. doi: 10.2166/ wst. 2019.060

18. Leong YK, Chang JS. Bioremediation of heavy metals using microalgae: Recent advances and mechanisms. Bioresour Technol. 2020;303:122886. doi: 10.1016/j. biortech.2020.122886

19. Huang H, Wu K, Khan A, et al. A novel Pseudomonas gessardii strain LZ-E simultaneously degrades naphthalene and reduces hexavalent chromium. Bioresour Technol. 2016;207:370-378. doi: 10.1016/j. biortech.2016.02.015

20. Velasquez L, Dussan J. Biosorption and bioaccumulation of heavy metals on dead and living biomass of Bacillus sphaericus. J Hazard Mater. 2009;167(1-3):713-716. doi: 10.1016/j.jhazmat.2009.01.044

21. Srinath T, Verma T, Ramteke PW, Garg SK. Chromium (VI) biosorption and bioaccumulation by chromate resistant bacteria. Chemosphere. 2002;48(4):427-435. doi: 10.1016/s0045-6535(02)00089-9

22. Timkova I, Sedlakova-Kadukova J, Pristas P. Biosorption and bioaccumulation abilities of actinomycetes/ streptomycetes isolated from metal contaminated sites. Separations. 2018;5(4):54. doi: 10.3390/ separations 5040054

23. Juhnke S, Peitzsch N, Hubener N, Grosse C, Nies $\mathrm{DH}$. New genes involved in chromate resistance in Ralstonia metallidurans strain $\mathrm{CH}_{34}$. Arch Microbiol.
2002;179(1):15-25. doi: 10.1007/s00203-002-0492-5

24. Chardin B, Giudici-Orticoni MT, De Luca G, Guigliarelli $B A$, Bruschi M. Hydrogenases in sulfate-reducing bacteria function as chromium reductase. Appl Microbiol Biotechnol. 2003;63(3):315-321. doi: 10.1007/s00253-003-1390-8

25. Fernandez PM, Martorell MM, Blaser MG, Ruberto LAM, Figueroa LIC, Mac WP. Phenol degradation and heavy metal tolerance of Antarctic yeasts. Extremophiles. 2017;21(3):445-457. doi: 10.1007/ s00792-017-0915-5

26. Kathiravan MN, Karthick R, Muthu N, Muthukumar K, Velan M. Sonoassisted microbial reduction of chromium. Appl Microbiol Biotechnol.2010;160(7):2000-2013. doi: 10.1007/s12010-009-8716-7

27. Ahmad WA, Ahmad WHW, Karim NA, Raj AS, Zakaria $\mathrm{ZA}$. $\mathrm{Cr}(\mathrm{VI})$ reduction in naturally rich growth medium and sugarcane bagasse by Acinetobacter haemolyticus. Int Biodeterior Biodegradation. 2013;85:571-576. doi: 10.1016/j.ibiod.2013.01.008

28. Xu L, Luo M, Li W, et al. Reduction of hexavalent chromium by Pannonibacter phragmitetus LSSE-09 stimulated with external electron donors under alkaline conditions. J Hazard Mater. 2011;185(23):1169-1176. doi: 10.1016/j.jhazmat.2010.10.028

29. Liu YG, Xu WH, Zeng GM, Li X, Gao H. Cr(VI) reduction by Bacillus sp. isolated from chromium landfill. Process Biochemistry. 2006;41(9):1981-1986. doi: 10.1016/j. procbio.2006.04.020

30. Jobby R, Jha P, Yadav AK, Desai N. Biosorption and biotransformation of hexavalent chromium [ $\mathrm{Cr}(\mathrm{VI})]$ : a comprehensive review. Chemosphere. 2018;207:255266. doi: 10.1016/j.chemosphere.2018.05.050

31. Wani R, Kodam KM, Gawai KR, Dhakephalkar PK. Chromate reduction by Burkholderia cepacia MCMB821 ,isolated from the pristine habitat of alkaline crater lake. Appl Microbiol Biotechnol. 2007;75(3):627-632. doi: 10.1007/s00253-007-0862-7

32. Retnaningrum E, Yulianti DM, Wilopo W. Chromium Precipitation Activity and Molecular Characterization of Sulfate-Reducing Bacteria. Journal of Applied Geology. 2019;4(1):15-19. doi: 10.22146/jag.48737

33. Abbas SH, Ismail IM, Mostafa TM, Sulaymon AH. Biosorption of heavy metals: a review. Journal of Chemical Science and Technology. 2014;3(4):74-102.

34. Sahin Y, Ozturk A. Biosorption of chromium(VI) ions from aqueous solution by the bacterium Bacillus thuringiensis. Process Biochemistry. 2005;40(5):18951901. doi: $10.1016 / j$.procbio.2004.07.002

35. Tariq SR, Shah MH, Shaheen N, Khalique A, Manzoor $S$, Jaffar M. Multivariate analysis of selected metals in tannery effluents and related soil. $J$ Hazard Mater. 2005;122(1):17-22. doi: 10.1016/j. jhazmat.2005.03.017

36. Ziagova M, Dimitriadis G, Aslanidou D, Papaioannou X, Tzannetaki EL, Liakopoulou-Kyriakides M. Comparative study of $\mathrm{Cd}(\mathrm{II})$ and $\mathrm{Cr}(\mathrm{VI})$ biosorption on Staphylococcus xylosus and Pseudomonas sp. in single and binary mixtures. Bioresour Technol. 2007;98(15):2859-2865. doi: 10.1016/j.biortech.2006.09.043

37. Aslam F, Yasmin A, Sohail S. Bioaccumulation of lead, chromium, and nickel by bacteria from three different 
genera isolated from industrial effluent. Int Microbiol. 2020;23(2):253-261. doi: 10.1007/s10123-01900098-W

38. Naik UC, Srivastava S, Thakur IS. Isolation and characterization of Bacillus cereus IST105 from electroplating effluent for detoxification of hexavalent chromium. Environ Sci Pollut Res Int. 2012;19(7):30053014. doi: 10.1007/s11356-012-0811-6

39. Pulimi M, Jamwal S, Samuel J, Chandrasekaran N, Mukherjee A. Enhancing the hexavalent chromium bioremediation potential of Acinetobacter junii VITSUKMW2 using statistical design experiments. J Microbiol Biotechnol. 2012;22(12):1767-1775. doi: 10.4014/jmb.1203.03063

40. Ajao AT, Adebayo GB, Yakubu SE. Bioremediation of textile industrial effluent using mixed culture of Pseudomonas aeruginosa and Bacillus subtilis immobilized on agar-agar in a bioreactor. Journal of Microbiology and Biotechnology Research. 2011;1(3):50-56.

41. Saranraj P, Stella D, Reetha D, Mythili K. Bioadsorption of chromium resistant Enterococcus casseliflavus isolated from tannery effluents. Journal of Ecobiotechnology. 2010;2(7):17-22.

42. Prabhakaran DC, Subramanian S. Studies on the bioremediation of chromium from Aqueous Solutions Using C. paurometabolum. Transactions of the Indian Institute of Metals. 2017;70(2):497-509. doi: 10.1007/ s12666-016-1009-2

43. Myers CR, Carstens BP, Antholine WE, Myers JM. Chromium(VI) reductase activity is associated with the cytoplasmic membrane of anaerobically grown Shewanella putrefaciens MR-1. J Appl Microbiol. 2000;88(1):98-106. doi: 10.1046/j.13652672.2000.00910.x

44. Quilntana $M$, Curutchet $G$, Donati E. Factors affecting chromium(VI) reduction by Thiobacillus ferrooxidans. Chem Eng J. 2001;9(1):11-15. doi: 10.1016/\$1369703X(01)00116-4

45. Singh $\mathrm{R}$, Dong $\mathrm{H}$, Liu $\mathrm{D}$, et al. Reduction of hexavalent chromium by the thermophilic methanogen Methanothermobacter thermautotrophicus. Geochim Cosmochim Acta. 2015;148:442-456. doi: 10.1016/j. gca.2014.10.012

46. Malekzadeh F, Mashkani SG, Ghafourian H, Soudi MR. Biosorption of tungstate by a Bacillus sp. isolated from Anzali lagoon. World J Microbiol Biotechnol. 2007;23(7):905-910. doi: 10.1007/s11274-006-9313-3

47. Tharannum S. Bioremediation of hexavalent chromium from electroplating effluents by wild and mutant strains of Bacillus amyloliquifaciens. Indian J Exp Biol. 2020;58(10):722-729.

48. Abo Elazm A, El-Rahim A, Mohamed W, Sabbor AT, Moawad H, Sedik MZ. Bioremediation of Hexavalent Chromium Widely Discharged in Leather Tanning Effluents. Egyptian Journal of Chemistry. 2020;63(6):2201-2212. doi: 10.21608/ ejchem.2019.18457.2142

49. Tariq M, Waseem M, Rasool MH, Zahoor MA, Hussain I. Isolation and molecular characterization of the indigenous Staphylococcus aureus strain K1 with the ability to reduce hexavalent chromium for its application in bioremediation of metal-contaminated sites. Peer J. 2019;7:e7726. doi: 10.7717/peerj.7726

50. Baldiris R, Acosta-Tapia N, Montes A, Hernandez J, Vivas-Reyes $R$. Reduction of hexavalent chromium and detection of chromate reductase (ChrR) in Stenotrophomonas maltophilia. Molecules. 2018;23(2):406.

51. Mohamed MS, El-Arabi NI, El-Hussein A, El-Maaty $\mathrm{SA}$, Abdelhadi AA. Reduction of chromium-VI by chromium-resistant Escherichia coli FACU: a prospective bacterium for bioremediation. Folia Microbiologica (Praha). 2020;65(4):687-696. doi: 10.1007/s12223-020-00771-y

52. Cummings $D E$, Fendorf $S$, Singh $N$, Sani RK, Peyton $\mathrm{BM}$, Magnuson TS. Reduction of $\mathrm{Cr}(\mathrm{VI})$ under acidic conditions by the facultative $\mathrm{Fe}(\mathrm{III})$-reducing bacterium Acidiphilium cryptum. Environ Sci Technol. 2007;41(1):146-152. doi: 10.1021/es061333k

53. KarthikC, RamkumarVS, Pugazhendhi A, Gopalakrishnan $\mathrm{K}$, Arulselvi PI. Biosorption and biotransformation of $\mathrm{Cr}(\mathrm{VI})$ by novel Cellulosimicrobium funkei strain AR6. J Taiwan Inst Chem Eng. 2017;70:282-290. doi: 10.1016/j.jtice.2016.11.006

54. Xie P, Hao X, Mohamad OA, Liang J, Wei G. Comparative study of chromium biosorption by Mesorhizobium amorphae strain CCNWGS0123 in single and binary mixtures. Appl Biochem Biotechnol. 2013;169:570-587.

55. Elangovan R, Philip L. Performance evaluation of various bioreactors for the removal of $\mathrm{Cr}(\mathrm{VI})$ and organic matter from industrial effluent. Biochemical Engineering Journal. 2009;44(2):174-186. doi: 10.1016/j.bej.2008.11.014

56. Sathishkumar K, Murugan K, Benelli G, Higuchi A, Rajasekar A. Bioreduction of hexavalent chromium by Pseudomonas stutzeri L1 and Acinetobacter baumannii L2. Ann Microbiol. 2016;67(1):91-98. doi: 10.1007/ s13213-016-1240-4

57. Ge S, Zheng W, Dong X, Zhou M, Zhou J, Ge $S$. Distributions of soluble hexavalent chromate reductase from Leucobacter sp. G161 with high reducing ability and thermostability. J Pure Appl Microbiol. 2014;8(3):1893-1900.

58. Das S, Mishra J, Das SK, et al. Investigation on mechanism of $\mathrm{Cr}(\mathrm{VI})$ reduction and removal by Bacillus amyloliquefaciens, a novel chromate tolerant bacterium isolated from chromite mine soil. Chemosphere. 2014;96:112-121.

59. Gunasundari D, Muthukumar K. Simultaneous $\mathrm{Cr}(\mathrm{VI})$ reduction and phenol degradation using Stenotrophomonas sp. isolated from tannery effluent contaminated soil. Environ Sci Pollut Res Int. 2013;20(9):6563-6573. doi: 10.1007/s11356-0131718-6

60. Panneerselvam P, Choppala G, Kunhikrishnan A, Bolan $\mathrm{N}$. Potential of novel bacterial consortium for the remediation of chromium contamination. Water, Air, \& Soil Pollution. 2013;224(12):1716. doi: 10.1007/ s11270-013-1716-9

61. Mishra RR, Dhal B, Dutta SK, Dangar TK, Das NN, Thatoi HN. Optimization and characterization of chromium (VI) reduction in saline condition by moderately halophilic Vigribacillus $\mathrm{sp}$. isolated 
from mangrove soil of Bhitarkanika, India. Journal of Hazardous Materials. 2012;227:219-226. doi: 10.1016/j.jhazmat.2012.05.063

62. Lytras G, Lytras C, Argyropoulou D, Dimopoulos N, Malavetas G, Lyberatos G. A novel two-phase bioreactor for microbial hexavalent chromium removal from wastewater. J Hazard Mater. 2017;336:41-51. doi: 10.1016/j.jhazmat.2017.04.049

63. Thacker U, Parikh R, Shouche Y, Madamwar D. Hexavalent chromium reduction by Providencia sp. Process Biochemistry. 2006;41(6):1332-1337. doi: 10.1016/j.procbio.2006.01.006

64. Deng $P$, Tan $X Q$, Wu Y, Bai QH, Jia Y, Xiao H. Cloning and sequence analysis demonstrate the chromate reduction ability of a novel chromate reductase gene from Serratia sp. Exp Ther Med. 2015;9:795-800. doi: 10.3892/etm.2014.2148

65. Yahya SK, Zakaria ZA, Samin J, Raj AS, Ahmad WA. Isotherm kinetics of $\mathrm{Cr}$ (III) removal by non-viable cells of Acinetobacter haemolyticus. Colloids Surfaces B Biointerfaces. 2012;94:362-368. doi: 10.1016/j. colsurfb.2012.02.016

66. Ganguli A, Tripathi A. Bioremediation of toxic chromium from electroplating effluent by chromate-reducing Pseudomonas aeruginosa $\mathrm{A} 2 \mathrm{Chr}$ in two bioreactors. Appl Microbiol Biotechnol. 2002;58(3):416-420. doi: 10.1007/s00253-001-0871-x

67. Ahluwalia SS, Goyal D. Microbial and plant derived biomass for removal of heavy metals from wastewater. Bioresour Technol. 2007;98(12):2243-2257. doi: 10.1016/j.biortech.2005.12.006

68. Donmez G, Aksu Z. The effect of copper(II) ions on the growth and bioaccumulation properties of some yeasts. Process Biochemistry. 1999;35(1-2):135-142. doi: 10.1016/s0032-9592(99)00044-8

69. Vendruscolo F, da Rocha Ferreira GL, Antoniosi Filho NR. Biosorption of hexavalent chromium by microorganisms. Int Biodeterior Biodegradation. 2017;119:87-95. doi: 10.1016/j.ibiod.2016.10.008

70. Villegas LB, Pereira CE, Colin VL, Abate CM. The effect of sulphate and phosphate ions on $\mathrm{Cr}(\mathrm{VI})$ reduction by Streptomyces sp. MC1, including studies of growth and pleomorphism. Int Biodeterior Biodegradation. 2013;82:149-156. doi: 10.1016/j.ibiod.2013.01.017

71. Rosca M, Hlihor RM, Cozma P, Comanita ED, Simion IM, Gavrilescu M. Potential of biosorption and bioaccumulation processes for heavy metals removal in bioreactors. In $2015 \mathrm{E}-$-Health and Bioengineering Conference (EHB). 2015:1-4. IEEE. doi: 10.1109/ EHB.2015.7391487

72. Pagnanelli F, Viggi CC, Cibati A, Uccelletti D, Toro L, Palleschi C. Biotreatment of $\mathrm{Cr}(\mathrm{VI})$ contaminated waters by sulphate reducing bacteria fed with ethanol. J Hazard Mater. 2012;199:186-192. doi: 10.1016/j. jhazmat.2011.10.082

73. Quintelas C, Rocha Z, Silva B, Fonseca B, Figueiredo $\mathrm{H}$, Tavares T. Removal of $\mathrm{Cd}(\mathrm{II}), \mathrm{Cr}(\mathrm{VI}), \mathrm{Fe}(\mathrm{III})$ and $\mathrm{Ni}(\mathrm{II})$ from aqueous solutions by an $E$. coli biofilm supported on kaolin. Chem Eng J. (Lausanne, Switzerland: 1996). 2009;149(1):319-324. doi: 10.1016/j.cej.2008.11.025

74. Cirik K, Dursun N, Sahinkaya E, Cinar O. Effect of electron donor source on the treatment of $\mathrm{Cr}(\mathrm{VI})$-containing textile wastewater using sulfate-reducing fluidized bed reactors (FBRs). Bioresour Technol. 2013;133:414-420. doi: 10.1016/j.biortech.2013.01.064

75. Nkhalambayausi-Chirwa EM, Wang YT. Simultaneous chromium(VI) reduction and phenol degradation in a fixed-film coculture bioreactor: reactor performance. Water Research (Oxford). 2001;35(8):1921-1932. doi: 10.1016/S0043-1354(00)00472-3

76. Morales-Barrera L, Cristiani-Urbina E. Removal of hexavalent chromium by Trichoderma viride in an airlift bioreactor. Enzyme Microb Technol. 2006;40(1):107113. doi: 10.1016/j.enzmictec.2005.10.044

77. Guillen-Jimenez FDM, Netzahuatl-Munoz AR, MoralesBarrera L, Cristiani-Urbina E. Hexavalent chromium removal by Candida sp. in a concentric draft-tube airlift bioreactor. Water, Air, and Soil Pollution. 2009;204(14):43-51. doi: 10.1007/s11270-009-0024-x

78. Han M, Laari A, Koiranen T. Hydrodynamic and mass transfer characteristics of annulus-rising airlift reactor the effect of reactor scale. MATEC Web of Conferences. 2016;49:4001. doi: 10.1051/matecconf/20164904001

79. Sharma S, Malaviya P. Bioremediation of tannery wastewater by chromium resistant novel fungal consortium. Ecol Eng. 2016;91:419-425. doi: 10.1016/j. ecoleng.2016.03.005

80. Camargo F, Okeke B, Bento F, Frankenberger W. Hexavalent chromium reduction by immobilized cells and the cell-free extract of Bacillus sp. ES 29. Bioremediation Journal. 2004;8(1-2):23-30. doi: 10.1080/10889860490453140

81. Konovalova VV, Dmytrenko GM, Nigmatullin RR, Bryk MT, Gvozdyak PI. Chromium(VI) reduction in a membrane bioreactor with immobilized Pseudomonas cells. Enzyme Microb Technol. 2003;33(7):899-907. doi: 10.1016/S0141-0229(03)00204-7

82. Robins KJ, Hooks DO, Rehm BH, Ackerley DF. Escherichia coli NemA is an efficient chromate reductase that can be biologically immobilized to provide a cell free system for remediation of hexavalent chromium. PloS ONE. 2013;8(3):59200. doi: 10.1371/journal. pone.0059200

83. He Z, Yao Y, Lu Z, Ye Y. Dynamic metabolic and transcriptional profiling of Rhodococcus sp. strain YYL during the degradation of tetrahydrofuran. Appl Environ Microbiol. 2014;80(9):2656-2664. doi: 10.1128/AEM.04131-13

84. Herrero $M$, Stuckey DC. Bioaugmentation and its application in wastewater treatment: A review. Chemosphere (Oxford). 2015;140:119-128. doi: 10.1016/j.chemosphere.2014.10.033

85. Ji J, Kulshreshtha S, Kakade A, Majeed S, Li X, Liu $P$. Bioaugmentation of membrane bioreactor with Aeromonas hydrophila LZ-MG14 for enhanced malachite green and hexavalent chromium removal in textile wastewater. Int Biodeterior Biodegradation. 2020;150:104939. doi: 10.1016/j.ibiod.2020.104939

86. Gutierrez-Corona JF, Romo-Rodriguez P, Santos-Escobar F, Espino-Saldana AE, Hernandez-Escoto H. Microbial interactions with chromium: basic biological processes and applications in environmental biotechnology. World J Microbiol Biotechnol. 2016;32(12):191. doi: 10.1007/s11274-016-2150-0 
87. Williams PJ, Botes E, Maleke MM, et al. Effective bioreduction of hexavalent chromium-contaminated water in fixed-film bioreactors. Water $S A$. 2014;40(3):549-554. doi: 10.4314/wsa.v40i3.19
88.

Kulshreshtha A, Agrawal R, Barar M, Saxena S. A review on bioremediation of heavy metals in contaminated water. IOSR J Environ Sci Toxicol Food Technol. 2014;8(7):44-50. doi: 10.9790/2402-08714450 